Review

\title{
Sustainable Shift from Centralized to Participatory Higher Education in Post-Soviet Countries: A Systematic Literature Review
}

\author{
Hasmik Hovakimyan ${ }^{1, *}$, Milena Klimek ${ }^{2}$, Bernhard Freyer ${ }^{2}$ and Ruben Hayrapetyan ${ }^{3}$ \\ 1 Institute for Sustainable Economic Development, Department of Economics and Social Sciences, \\ University of Natural Resources and Life Sciences, 1180 Vienna, Austria \\ 2 Division of Organic Farming, Department of Sustainable Agricultural Systems, University of Natural \\ Resources and Life Sciences, 1180 Vienna, Austria; milena.klimek@boku.ac.at (M.K.); \\ bernhard.freyer@boku.ac.at (B.F.) \\ 3 Department of Management, Armenian State University of Economics, Yerevan 0025, Armenia; \\ ruben.hayrapetyan@asue.am \\ * Correspondence: hasmik.hovakimyan@students.boku.ac.at; Tel.: +43-677-6269-8963
}

Citation: Hovakimyan, H.; Klimek, M.; Freyer, B.; Hayrapetyan, R. Sustainable Shift from Centralized to Participatory Higher Education in Post-Soviet Countries: A Systematic Literature Review. Sustainability 2021, 13, 5536. https://doi.org/10.3390/ su13105536

Academic Editors: Daniel Schiller and Verena Radinger-Peer

Received: 14 April 2021

Accepted: 12 May 2021

Published: 15 May 2021

Publisher's Note: MDPI stays neutral with regard to jurisdictional claims in published maps and institutional affiliations.

Copyright: (c) 2021 by the authors. Licensee MDPI, Basel, Switzerland. This article is an open access article distributed under the terms and conditions of the Creative Commons Attribution (CC BY) license (https:/ / creativecommons.org/licenses/by/ $4.0 /)$.

\begin{abstract}
Since the fall of the Soviet Union, higher education (HE) in post-Soviet reality continues to face complex challenges, including hierarchical structures, antiquated teaching methods, and lack of international standards. In the meantime, in the US and in Europe, HE has recently focused on participatory curriculum development (PCD) and programs that seek to directly connect student learning to "real-world" problems, accelerating positive change in curricula and through their contributions to regional communities. Accepted into the Bologna Process-the standardization of European HE-Armenian HE institutions struggle to satisfy requirements and related sustainable development goals with centralized standards, inhibiting them from being internationally competitive and regional sustainability change agents. In this article, we examine post-Soviet HE development since 1991 and challenges, with a particular focus on Armenia; what participatory curriculum building may offer; and how it contributes to $\mathrm{HE}$ and regional sustainability transitions. A systematic literature review was applied, using specific combinations of important terms restricting the search with criteria such as language, year of publication, and descriptive or critical in nature. The results illustrate the status quo of post-Soviet HE, synthesize current barriers of $\mathrm{HE}$ as potential change agents, and highlight $\mathrm{PCD}$ as a way to overcome these barriers.
\end{abstract}

Keywords: Armenia; higher education; participatory curriculum development; post-Soviet countries; stakeholder participation; sustainability

\section{Introduction}

After persistence for more than seven decades, the Soviet Union-a "union" of 15 states spanning a sixth of the world's terrain-collapsed in 1991, claiming the start of social, economic, and political disbalances in now-independent member countries [1]. Armenia, as one the 15 states-with nearly 30,000 square kilometers of territory and a population just shy of 3 million-was hit significantly after gaining its independence in September 1991. Years of a lasting energy crisis and structural gaps represented the particular challenges of that time [2]. The transition to emergent independence did not go smoothly for any former member state. The absence of structural changes underlined the need for transformation in many sectors. The educational sector, and particularly the university system - centralized and static-held potential to meet labor market needs and assist as agents of change in rebuilding regional economies [3]. Though former member countries followed similar pathways of educational reforms, the problems and the gaps the states were facing varied from one another [3]. The countries of the South Caucasus were remodeling their HE systems from a much more difficult starting point. Statehood absence 
for many centuries led to adverse conditions for the development of national educational traditions [4]. The transformation of the educational system in Armenia (as in most former Soviet Union member countries) continues today, highlighting the need for compatibility at an international scale. To lead this transformation toward sustainability and to comply with sustainable development goals (SDGs) requires a paradigm shift, particularly in HE $[5,6]$. Here, we suggest PCD as one step toward such a paradigm shift [7]. HE institutions can play a significant role in contributing to sustainable development within their regional communities [8,9]. This is especially the case as sustainability stems from the interaction of innumerable economic, political, social, and cultural factors [10,11]. The educational sector is not only situated within these environments; it is often, as in the case with HE, expected to critically question and give back to them [12]. Currently, the Armenian educational system faces the vital urgency of structural reforms, especially in the modernization and internationalization of its HE institutions (HEIs). University structures and procedures must be reshaped in order to better target real-world problems, and attract and integrate more stakeholders, thus becoming agents of change for their regional and professional communities, as well as fostering sustainable development within their impact areas. One of the crucial preconditions for reaching these objectives is the improvement and, in some cases, the initial development of PCD practices. This article offers the status quo of the current HE system in Armenia and draws the readers' attention to the contribution PCD could play in tackling some of the barriers found in the system and supporting the United Nation's SDGs.

Since Glasnost (a post-Soviet policy aimed at bringing former Soviet countries wider access to censored literature in libraries, freedom of speech, and transparency in media [13]), communication and information exchange has increased between Russia and former Soviet countries with Western countries [14,15]. This has opened up many possibilities for HE. While the classical top-down approach of teaching is still common in Eastern countries [16], in the last decades, Western countries' teaching and learning approaches have moved toward systemic practice by changing roles of students and teachers toward a more participatory and learning-oriented approach [17] — facilitation of student learning, with students becoming much more involved in the teaching process and responsible for their learning, and becoming project-oriented and discussion-based, rather than the passive listeners of a lecture. Part of this change has occurred through inter-/transdisciplinarity and case-study-oriented learning, where critical thinking and practical knowledge have become increasingly central characteristics. Today, there is consensus that from a pedagogical and learning perspective, and considering applicability to the work force, such modern approaches are far more successful than the former hierarchical pedagogical approaches [18].

Today, complex societal problems demand research and education integrate holistic, system-based thinking that can solve real-world problems. Large disruptions to our ecological, economic, and social structures, such as climate change and the current COVID-19 pandemic, represent prescient challenges that $\mathrm{HE}$ is expected to address. To fit these demands, the modernization and internationalization of universities and HE institutions include the improvement of curricula and their development. In contrast to former practices, contemporary curriculum-development processes increasingly involve a wide range of different stakeholders $[19,20]$. The integration of not only staff and students, but also policymakers, government officials, business owners, and citizens related to a particular curriculum theme, enables universities to act as agents of sustainable change in the regions they are embedded within and beyond, as they include the values and practices of specific actors in relation to their respective real-world problems. With this participatory curriculum development, the local, regional, or even transnational societal trends and needs are well integrated [21]. As a consequence, internationalization in teaching and learning further asks for the integration of a versatile transnational perspective on curricula, learning methods, and approaches. 
Worldwide, there is an ongoing adaptation of teaching and learning methods, in which students should become more active and creative in their learning processes [22]. In the meantime, there is higher awareness of participatory methods in the learning processes applied in a more collaborative manner and shared between students, teachers, researchers, and societal stakeholders [23]. However, in many post-Soviet countries, Armenia included, mechanisms are lacking in order to optimize societal involvement, thus ensuring that the perspectives of stakeholders are integrated [24].

These introductory reflections led to the following objectives of this systematic review: (1) to provide an overview of the status quo of HE in post-Soviet countries, with focus on the curricula-development process, and learning and teaching methods (see Section 3.2); (2) to identify current challenges of HE in post-Soviet countries, using Armenia as an example (see Section 3.3); and (3) to identify the potential that transformation into a participatory HE has to offer for a country's sustainability - again with a particular focus on Armenia (see Section 3.4).

\section{Methods}

A systematic literature review structured into four steps-suggested by Kitchenham and Charters (2007) —was applied for identifying the most relevant literature [25] (see Figure 1). The focus was on the articles published between 1991—collapse of Soviet Unionand January 2020. The steps were repeated in the 2020 search to comply with the nature of "systematic literature review", following the PRISMA (Preferred Reporting Items for Systematic Reviews and Meta-Analyses) guidelines [26].

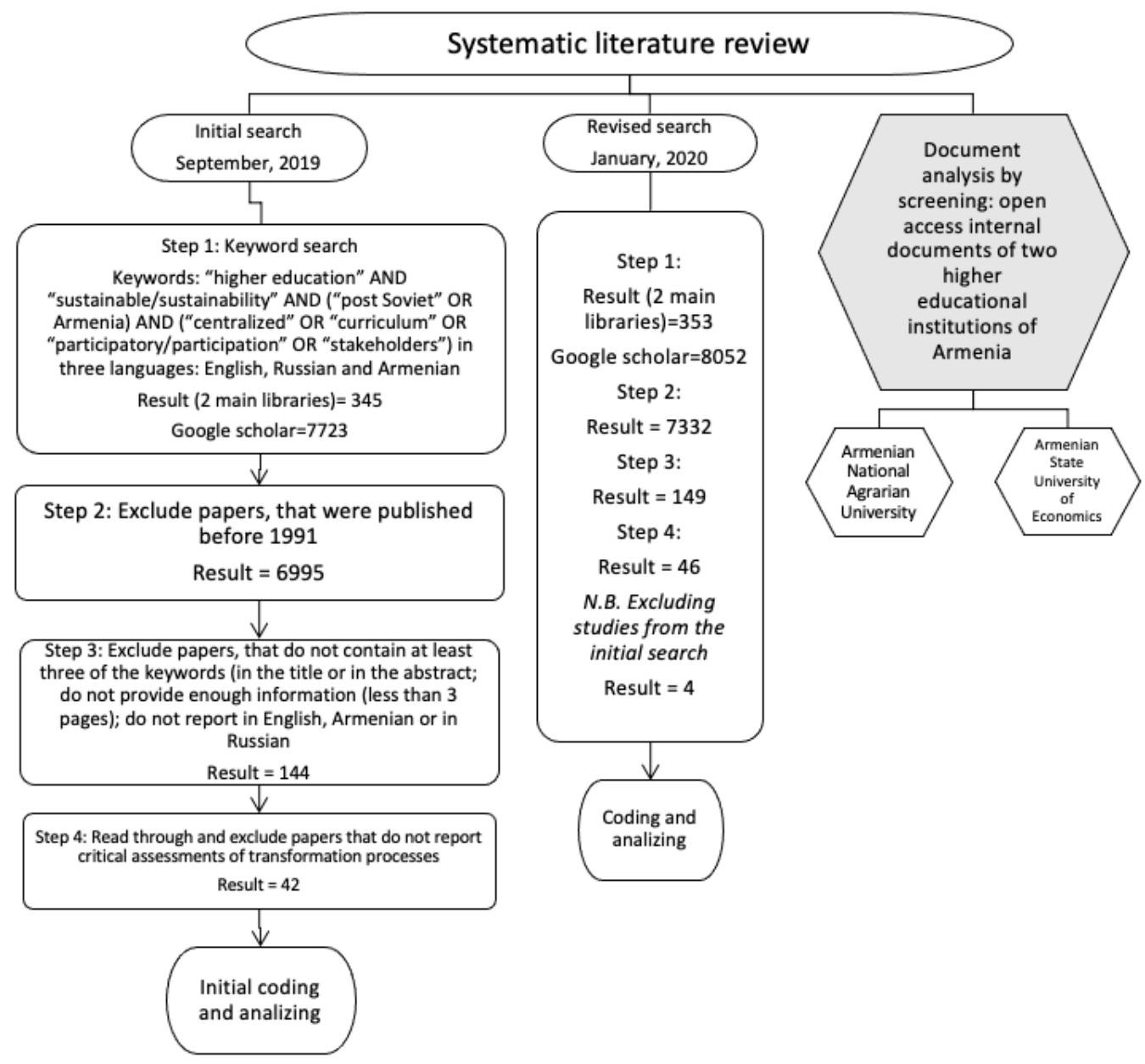

Figure 1. Systematic literature review: typology of the literature chosen and the steps conducted.

This review combined an initial search, a revised search, and a document analysis. 


\subsection{Initial Search (September 2019)}

Step 1: In the first step, we conducted a search using mandatory and optional combinations of the keywords: "higher education" AND "sustainable/sustainability" AND ("post-Soviet" OR Armenia) AND ("centralized" OR "curriculum" OR "participatory/participation" OR "stakeholders") in three languages-English, Russian, and Armenian. Integrating these languages allowed us to refer to the discourses and research on HE from diverse cultural backgrounds and experiences on HE. The selection of the terms refers to the defined objectives of this study and explains the problem stated in this article. Two main libraries were chosen for the main search: Scopus and ERIC (Education Resources Information Center). Among them, ERIC is more specialized in educational issues, while Scopus has a broader thematic focus, and searches all the most important databases from largest publishers. Google Scholar was included in the search as an additional and upto-date database to detect other research resources. As a result, we came up with a large number of studies-345 from the two libraries and 7723 from Google Scholar.

Step 2: The second step narrowed the search to year of the publication. The literature published before 1991 was excluded, orienting the search around the history of curricula development after the fall of the Soviet Union (with some exceptions that were important for the study, but were published before 1991). This provided us with 6995 results.

Step 3: The third step was carried out to filter irrelevant papers for this study by screening paper titles, keywords, and abstracts to identify those that were close to the topic. Papers that were not written in English, Russian, or Armenian, and papers not providing enough information (e.g., empirical evidence or primarily represented a meaning; less than 3 pages; or posters) were excluded as well. As a result, we came up with 144 papers in the initial search.

Step 4: For the fourth step, the resulting studies from the previous step were manually read through and the search was limited to studies employing critical assessments of the transformation processes in HE.

Results: Finally, 42 studies were selected for detailed revision-coding with terms "Armenia", "curriculum", "higher education", "participation", "post-Soviet countries", "sustainability", and "teaching and learning methods". These codes were developed initially (a priori codes) [27]. During the coding process, under each a priori code, "inductive codes" were developed [28] (Figure 2). The coding process was held by one coder (first author) in the period of less than a year.
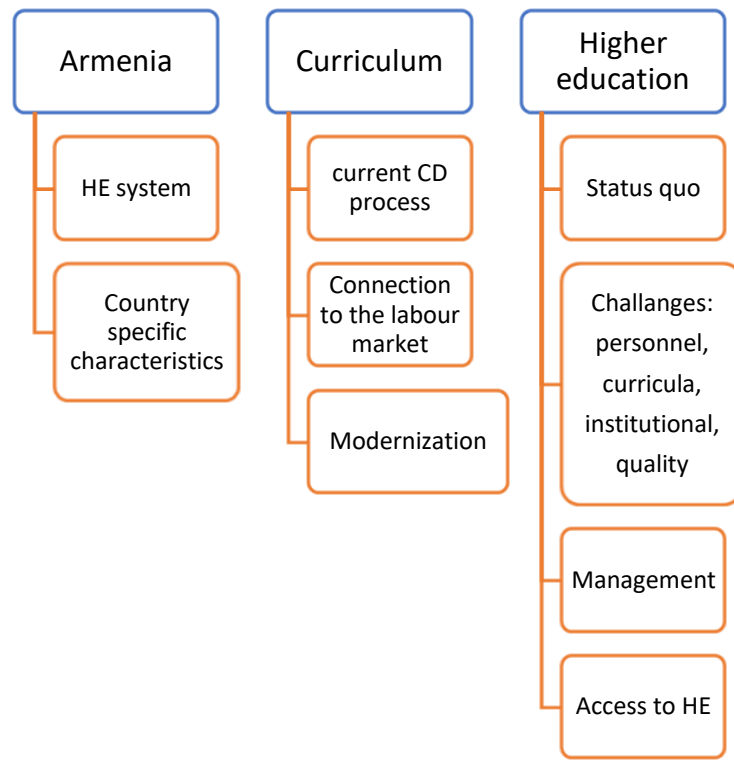
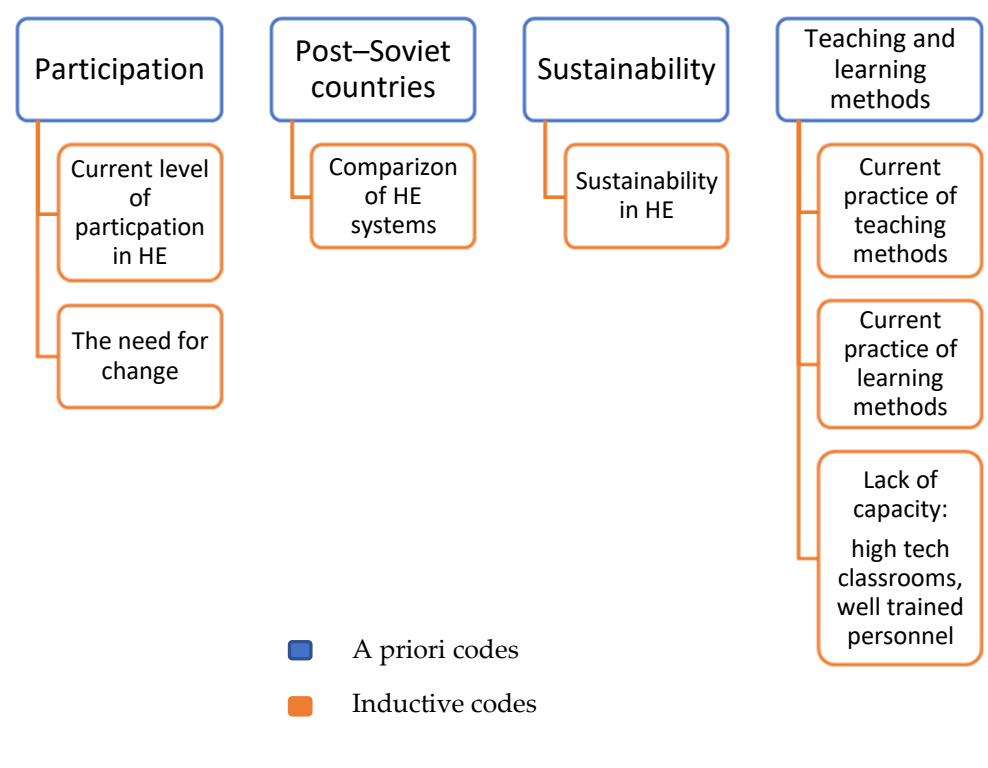

Figure 2. A detailed map of a priori and inductive codes. 


\subsection{Revised Search (January 2020)}

Step 1-4: In January 2020, a revised search was conducted to add any newly published works.

The same steps were taken as detailed above, and the search provided only a few new results.

Results: The revised search added four new articles on the top of already-selected articles during the initial search. Coding terms were the same as in the initial search.

In total, 46 papers were selected for this systematic review (Table 1).

\subsection{Document Analysis}

Additionally, around 30 internal documents (unpublished documents for universities' internal use, but accepted by the scientific councils of the universities) of two HEIs were screened continuously during September 2019 and January 2020 to identify the process of curriculum building in the specific universities. Those documents were coded only with the term "curriculum development" following our initial objective to expose the current CD process in Armenian HEIs.

\subsection{Detailed Review of Each Study}

The literature search as the main data collection method for the literature review involved making a choice on "the population of elements" that became the target of the study [29]. After the selection of 46 studies and around 30 internal documents of two Armenian HEIs with the codes illustrated above, we categorized all the findings in a priori code groups (Figure 3) and distinguished them by the year of the publication (Figure 4). Then, within each code group, publications were read and further coded with the inductive codes. Inductive coding (qualitative research) may sometimes deviate researchers from the initial objectives [30]. In this stage, we went back to our primary objectives to "justify" the inductive codes. Some inductive codes dropped, and the most relevant ones were grouped under initial a priori codes (Figure 2). During the inductive data analysis, the separate data points were collected, summarized, and integrated into a unified picture. Cooper (2015) suggested at this stage of the research to distinguish between the systematic data patterns and "the noise" [29]. The systematic data patterns we grouped are given in Sections 3.2-3.4, and also followed the objectives indicated initially. Finally, both deductive and inductive methods were used-from the problem to different studies, and from different studies to the problem. 
Table 1. Studies chosen for the systematic review and the codes applied.

\begin{tabular}{|c|c|c|c|c|}
\hline & Author(s) & Title/Publisher & Year of Publication & Study Relevant Codes Applied \\
\hline 1. & Shaeffer, S. & $\begin{array}{l}\text { Participatory approaches to teacher training. Teachers in developing countries: } \\
\text { Improving effectiveness and managing costs, pp. 187-200. }\end{array}$ & 1993 & $\begin{array}{c}\text { "curriculum", "participation", "teaching and } \\
\text { learning methods" }\end{array}$ \\
\hline 2. & Percy, R. & $\begin{array}{l}\text { Participatory curriculum development in agricultural education: a training guide: } \\
\text { Alan Rogers and Peter Taylor; Food and Agriculture Organisation (FAO), Rome, } \\
\text { 1998, 154p, ISBN 92-5-104272-1. Available free from Information Division, Food and } \\
\text { Agriculture Organisation of the United Nations, Viale delle Terme di Caracalla, } \\
\text { 00100 Rome, Italy., Pergamon. }\end{array}$ & 2000 & $\begin{array}{c}\text { "curriculum", "participation", "teaching and } \\
\text { learning methods" }\end{array}$ \\
\hline 3. & Platz, S. & $\begin{array}{l}\text { The Shape of National Time: Daily Life, History and Identity during Armenia's } \\
\text { Transition to Independence 1991-1994. Altering states: Ethnographies of transition } \\
\text { in Eastern Europe and the former Soviet Union: pp. 114-138. }\end{array}$ & 2000 & $\begin{array}{l}\text { "Armenia", "higher education", } \\
\text { "post-Soviet countries" }\end{array}$ \\
\hline 4. & Fullan, M. & The new meaning of educational change: Routledge. & 2001 & $\begin{array}{l}\text { "curriculum", "higher education", "sustainability", } \\
\text { "teaching and learning methods" }\end{array}$ \\
\hline 5. & Sterling, S. & $\begin{array}{l}\text { Higher education, sustainability, and the role of systemic learning, in Higher } \\
\text { education and the challenge of sustainability. Springer. pp. 49-70. }\end{array}$ & 2004 & $\begin{array}{l}\text { "curriculum", "higher education", "sustainability", } \\
\text { "teaching and learning methods" }\end{array}$ \\
\hline 6. & $\begin{array}{l}\text { Kozma, T. and T. } \\
\text { Polonyi }\end{array}$ & $\begin{array}{l}\text { Understanding education in Europe-East: Frames of interpretation and comparison. } \\
\text { International Journal of Educational Development, 24(5): pp. 467-477. }\end{array}$ & 2004 & "higher education", “teaching and learning methods" \\
\hline 7. & $\begin{array}{l}\text { Stefanou, C.R., } \\
\quad \text { et al. }\end{array}$ & $\begin{array}{l}\text { Supporting autonomy in the classroom: Ways teachers encourage student decision } \\
\text { making and ownership. Educational psychologist,. 39(2): pp. 97-110. }\end{array}$ & 2004 & $\begin{array}{c}\text { "higher education", "participation", "teaching and } \\
\text { learning methods" }\end{array}$ \\
\hline 9. & $\begin{array}{l}\text { Ghukasyan, A., L. } \\
\text { Asatryan, and A. } \\
\text { Karapetyan, }\end{array}$ & $\begin{array}{l}\text { Management of Pedagogical University and development trends" } \\
\text { Scientific-methodical manual (in Armenian). Mankavarzh. }\end{array}$ & 2005 & $\begin{array}{l}\text { "Armenia", "curriculum", "higher education", } \\
\text { "teaching and learning methods" }\end{array}$ \\
\hline 10. & Carl, A. & $\begin{array}{l}\text { The "voice of the teacher" in curriculum development: a voice crying in the } \\
\text { wildernes. South African Journal of Education, 25(4): pp. 223-228. }\end{array}$ & 2005 & $\begin{array}{l}\text { "curriculum", “higher education", "participation", } \\
\text { "teaching and learning methods" }\end{array}$ \\
\hline 11. & Petrosyan, H. & $\begin{array}{l}\text { Issues of Educational Program Accreditation (in Armenian). Lraber: Social Sciences. } \\
\text { 1: pp. 112-125. }\end{array}$ & 2007 & $\begin{array}{l}\text { "Armenia", "curriculum", “higher education”, } \\
\text { "participation", "post-Soviet countries" }\end{array}$ \\
\hline 12. & Blonder, R., et al. & $\begin{array}{l}\text { Increasing Science Teachers' Ownership through the Adaptation of the PARSEL } \\
\text { Modules: A" Bottom-up" Approach. Science Education International, 19(3): } \\
\text { pp. 285-301. }\end{array}$ & 2008 & $\begin{array}{l}\text { "curriculum", "higher education", "participation", } \\
\text { "teaching and learning methods" }\end{array}$ \\
\hline 13. & Mason, M. & $\begin{array}{l}\text { Making educational development and change sustainable: Insights from complexity } \\
\text { theory. International Journal of Educational Development. 29(2): pp. 117-124. }\end{array}$ & 2009 & $\begin{array}{c}\text { "higher education", "sustainability", "teaching and } \\
\text { learning methods" }\end{array}$ \\
\hline 14. & Shahverdyan, A. & $\begin{array}{l}\text { The Mismatch of Higher education (supply) and the labor market (demand) (in } \\
\text { Armenian). Kantegh: A collection of scientific articles, 3: pp. 249-254. }\end{array}$ & 2009 & $\begin{array}{l}\text { "Armenia", “curriculum", “higher education", } \\
\text { "participation", "post-Soviet countries", } \\
\text { "sustainability", “teaching and learning methods" }\end{array}$ \\
\hline
\end{tabular}


Table 1. Cont.

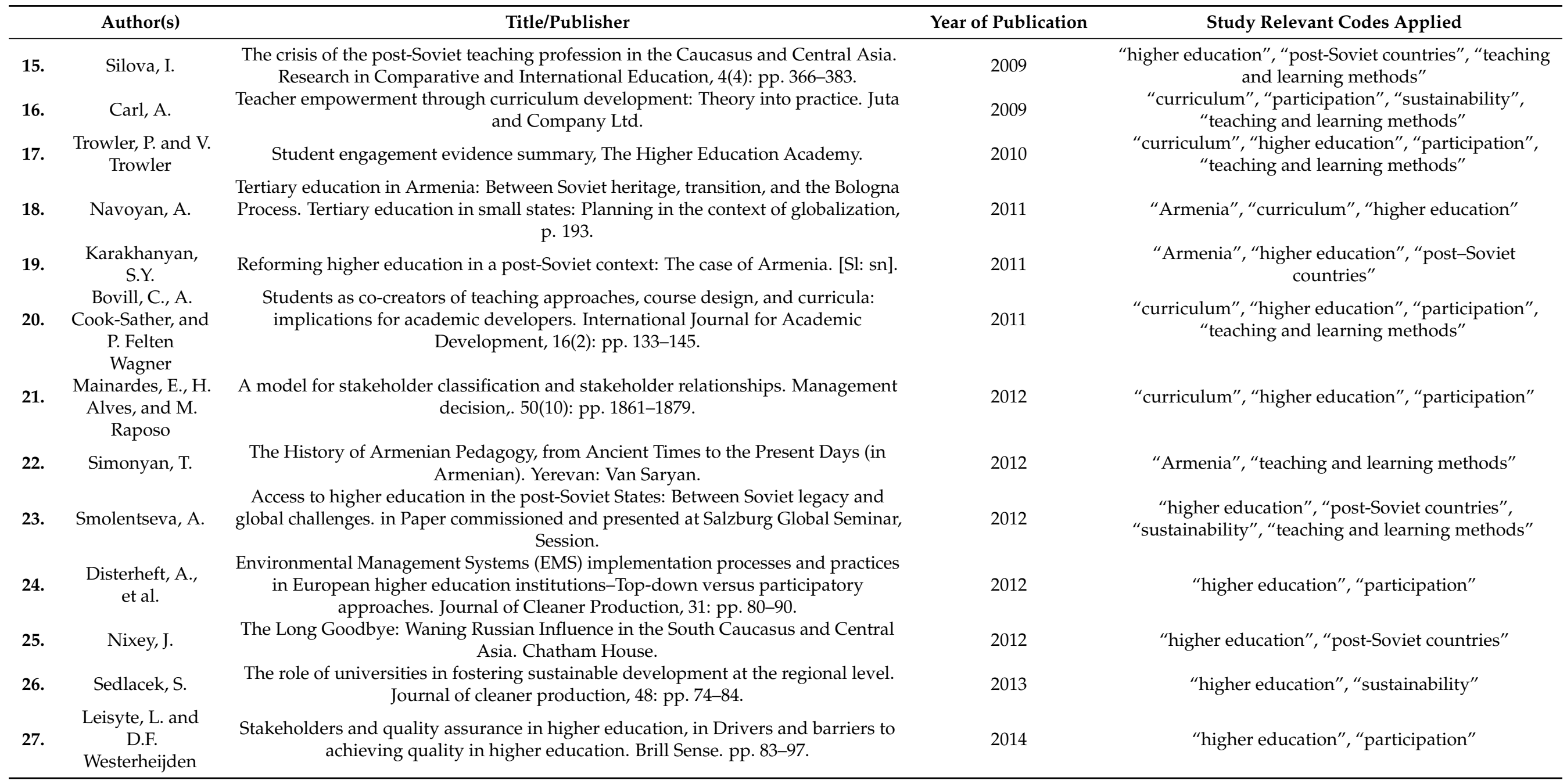


Table 1. Cont.

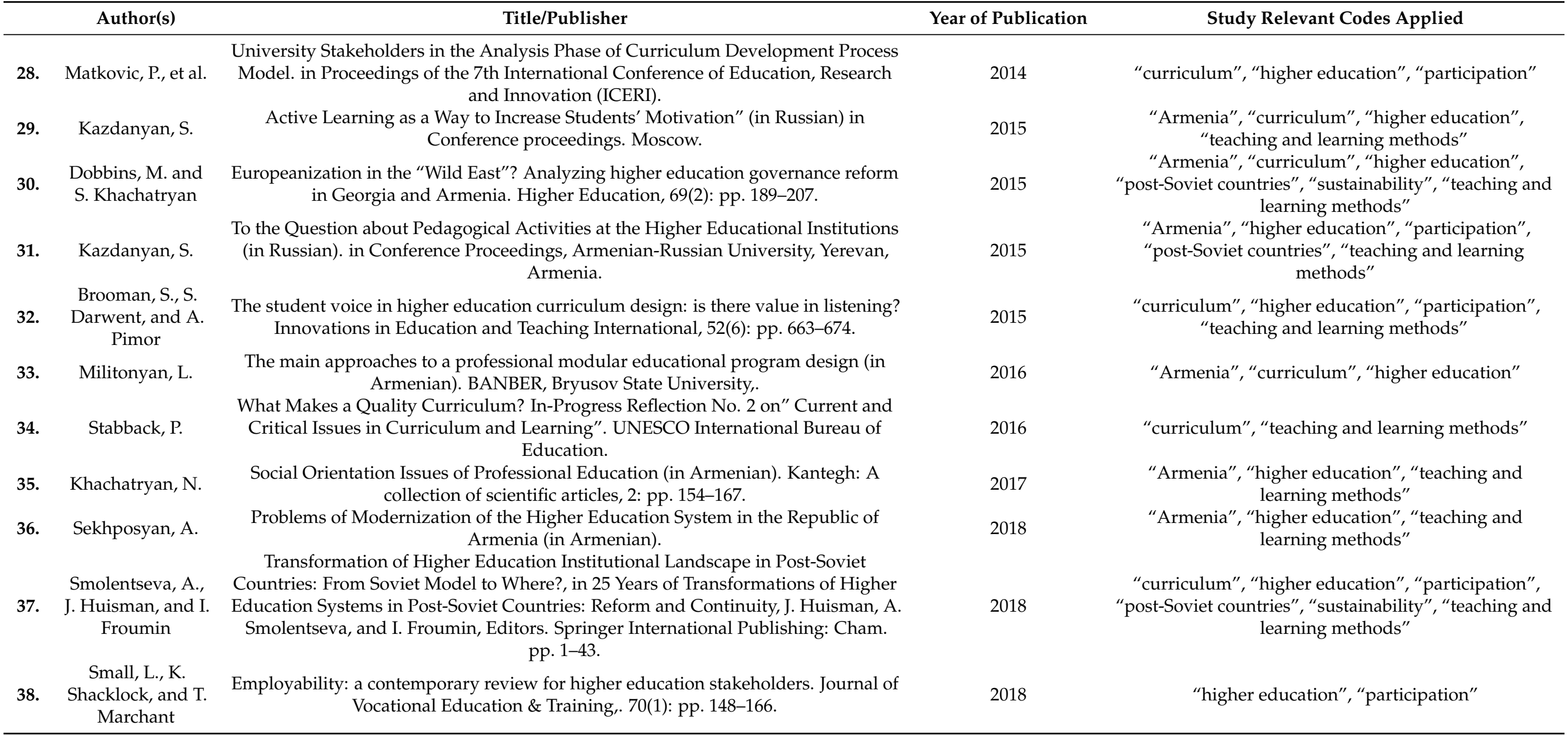


Table 1. Cont.

Author(s)

Prokofiev, M., M.

39. Chilikin, and S. Tulpanov

Connelly, F.M.

40. and D.J.

Clandinin

Imber, M., W.

41. Neidt, and P.

Reyes

42. Kerr, S.T

Alexander, I.K and C.N. Hjortsø

Solís-Espallargas, C., et al. Ruesch

5. Schweizer, C., A

Di Giulio, and P.

Burkhardt-Holm

Cebrián, G., M.

46. Junyent, and I. Mulà

Title/Publisher

Year of Publication

Study Relevant Codes Applied

\section{Exceptions:}

\section{Publications before the collapse of the Soviet Union in 1991}

Higher education in the USSR. Vol. Educational studies and documents, N39, Paris: UNESCO. 59.

1961

Teachers as Curriculum Planners. Narratives of Experience. ERIC.

Teacher participation in school decision making Teachers and their workplace: Commitment, performance, and productivity 1990 Newbury Park. CA Sage, 67: p.

Research news and Comment: Will Glasnost Lead to Perestroika? Directions of Educational Reform in the USSR. Educational researcher, 19(7): pp. 26-31.

$$
\text { Revised search results: }
$$

\section{Studies added after the revised search in 2020}

Sources of complexity in participatory curriculum development: an activity system and stakeholder analysis approach to the analyses of tensions and contradictions. Higher Education, 77(2): pp. 301-322.

Sustainability in the University: A Study of Its Presence in Curricula, Teachers and Students of Education. Sustainability,. 11(23): p. 6620.

Scientific Support for Redesigning a Higher-Education Curriculum on Sustainability. Sustainability, 11(21): p. 6035 research developments, Sustainability, 12(2): 597

"curriculum", “higher education”, “post-Soviet countries"

"curriculum", “higher education”, "participation”

"curriculum", "higher education", "participation", "teaching and learning methods"

"curriculum", "higher education", "post-Soviet countries", "teaching and learning methods"

"curriculum", "higher education", "participation", "sustainability", "teaching and learning methods"

"curriculum", “higher education", "participation", "sustainability", "teaching and learning methods"

"curriculum", "higher education", "sustainability"

"higher education", "sustainability", "teaching and learning methods" 


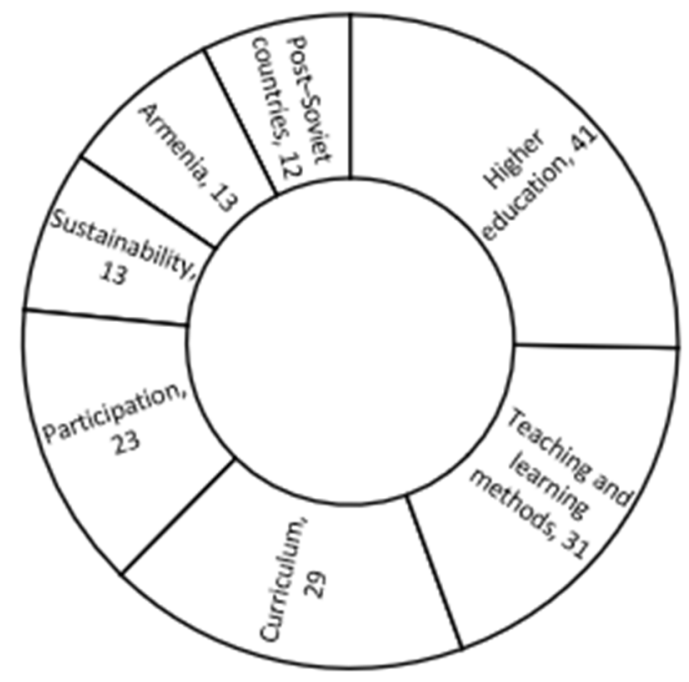

Figure 3. Number of studies relevant for each a priori code.

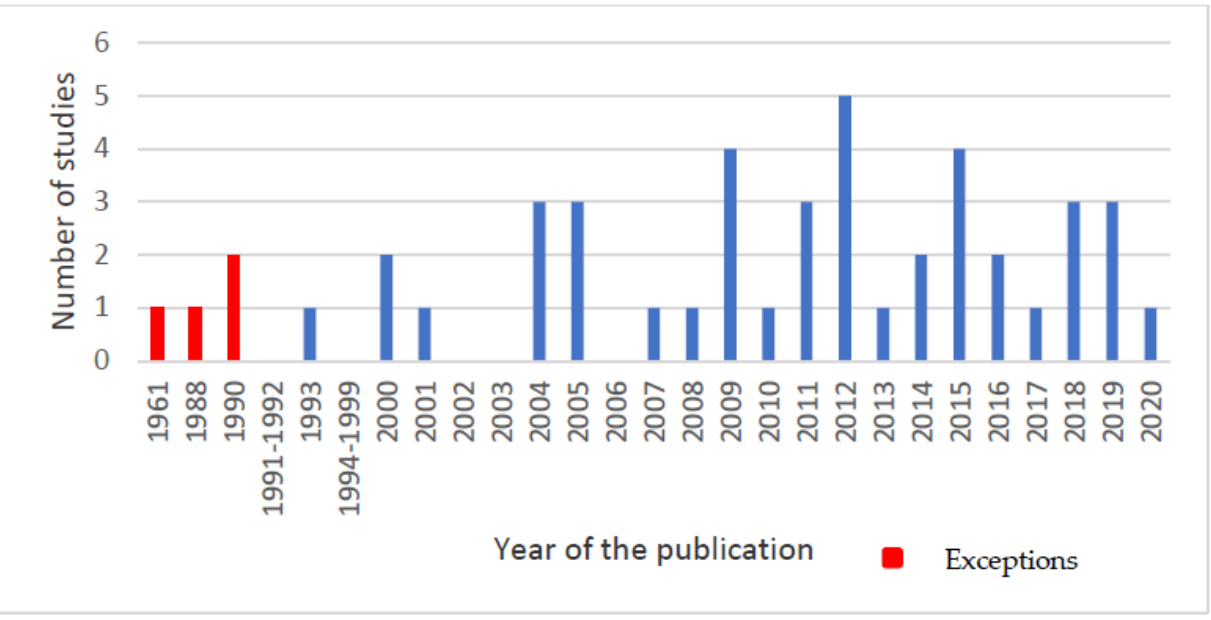

Figure 4. Distribution of the selected studies by year from 1991 to 2020 (with exceptions).

\section{Results}

\subsection{Performance Analysis}

The search results comprised 46 studies from 1991 to 2020, with a few exceptions that were important for this study, and around 30 internal documents from two HEIs. The distribution of the publications over 59 years is shown in Figure 4. The most significant number of studies selected was in 2012, with 5 publications. This distribution did not illustrate obvious growth or decrease.

Table 1 lists the 46 studies selected for this systematic review. The last column presents a priori codes relevant for each publication.

Studies with the same a priori codes were categorized under each code group (Figure 3).

\subsection{Background and Status Quo of the Current Higher Education System in Armenia}

In Soviet times, Armenia had a state-centered HE model [31]. The Soviet Education Ministry was in charge of planning and controlling all aspects of HE institutions. Within this centralized system, teaching and research were disconnected functionally: while universities focused on teaching, research was uptaken by a separate institution-the Academy of Science and Research [4,32]—distancing teaching from science.

After the fall of the Soviet Union in 1991, the teaching profession status began to be undermined in Armenia, as witnessed in such criteria as "a teacher shortage, the feminization 
of the profession, an over-aged teaching force, a low transition rate from teacher education graduation to professional service, and a decrease of enrollment in teacher education programs at colleges and universities" [33]. There were attempts to transform the educational system since the collapse of communism; however, they hit many obstacles [34,35]. A new HE framework in Armenia was formed at the beginning of the 1990s, and was significantly influenced by the new fragile economic and political institutions.

The fundamental restructuring of the educational system caused less state funding, resulting in the closure of most universities in the early 1990s. In 1992, tuition fees were introduced, which were an important source of income for many universities to operate further. Soon a high rate of admission was registered for popular subjects; e.g., economics, law, and international relations, despite the high tuitions and poor teaching quality [4].

In addition to the state universities, several private universities (usually with foreign capital and attractive foreign names) were established, which usually served as a "second chance" for those students who did not pass state admissions examinations. The boost of the private sector challenged the state's poor teaching quality and lack of infrastructure such as library resources and research laboratories, etc. During this time, many Armenian (and Georgian) state and private universities afflicted by heavy corruption-bribes for admission, obligatory books authored by professors and sold to students, mandatory preparatory lessons for examinations, etc. [36].

As mentioned above, the centralized HE system required the participation of the state in the controlling of and decision-making for HE policy, curricula, and teaching and learning methods (Figure 5a). After the collapse of Soviet Union, member states eventually gained their independence. Education, together with other sectors, entered a transformation process from the "centralized" system toward the "partly independent" current model (Figure 5b). A detailed description of the drivers and barriers mentioned in Figure 5 is provided in Table 2.

Table 2. The description of the drivers and barriers presented in Figure 2.

\begin{tabular}{|c|c|c|}
\hline $\begin{array}{l}\text { Drivers and } \\
\text { Barriers }\end{array}$ & $\begin{array}{l}\text { Description for Figure 5a: } \\
\text { The Centralized System of Higher Education in } \\
\text { the Soviet Era }\end{array}$ & $\begin{array}{l}\text { Description for Figure 5b: } \\
\text { Current Higher Education System in Post-Soviet Member States }\end{array}$ \\
\hline 1. Market & $\begin{array}{l}\text { State (Soviet Union) had full control over the } \\
\text { production and economy in all the member states. } \\
\text { The decisions were made for the whole production } \\
\text { value chain in the market. }\end{array}$ & $\begin{array}{l}\text { States (former member states) entered a market economy, which was } \\
\text { ruled by the law of supply and demand, so the state partly lost its } \\
\text { controlling function over types and quantity of the production in the } \\
\text { economy (taxes and laws are a regulating tool). }\end{array}$ \\
\hline 2. Labor market & $\begin{array}{l}\text { The labor market was controlled by the } \\
\text { state-identifying need for production types and } \\
\text { making decisions on the demand of quantity and } \\
\text { types of specialists for the economy. For example, } \\
\text { the industrialization of the country required an } \\
\text { increase in training of engineers. }\end{array}$ & $\begin{array}{l}\text { The labor market was not an exception. Here again, states had lost } \\
\text { their control, and the law of demand and supply had started } \\
\text { functioning with significant disorder. The connection of curricula and } \\
\text { labor market demand was quite weak. }\end{array}$ \\
\hline 3. HE management & $\begin{array}{l}\text { The state bore all the expenses of the construction } \\
\text { of buildings, equipment, salaries to the professors, } \\
\text { maintenance of students, and other expenses [31]. }\end{array}$ & $\begin{array}{l}\text { HE state institutions continued to be partly financed by states (and } \\
\text { from the tuition fees). }\end{array}$ \\
\hline 4. Access to HE & Education was mainly from a state stipend. & $\begin{array}{l}\text { Tuition fees were applied; a low number of state stipends were still } \\
\text { available. }\end{array}$ \\
\hline $\begin{array}{l}\text { 5. Quality of } \\
\text { education }\end{array}$ & $\begin{array}{l}\text { The universities were not autonomous. Decisions } \\
\text { on the curriculum and teaching and learning } \\
\text { methods were made to follow political grounds, } \\
\text { and there was no participation in these processes } \\
\text { by member states. }\end{array}$ & $\begin{array}{l}\text { Despite to all the changes that occurred during the transition period, } \\
\text { HE still continued in the old way of working: curricula were old, } \\
\text { educational programs did not meet the labor market demand, } \\
\text { teaching and learning methods hardly considered the needs of } \\
\text { students, and there was less participation by learners and by practical } \\
\text { specialists (stakeholders). }\end{array}$ \\
\hline $\begin{array}{l}\text { 6. Employment } \\
\text { after graduation }\end{array}$ & $\begin{array}{c}\text { Each graduate was entitled to a job for one or four } \\
\text { years after graduation. }\end{array}$ & $\begin{array}{c}\text { Today, the job market is incredibly challenging for a young, } \\
\text { inexperienced graduate in Armenia. }\end{array}$ \\
\hline
\end{tabular}

Source: The table was made by the authors by collecting and summarizing the information from the review process. Note: The table describes Figure 5. 


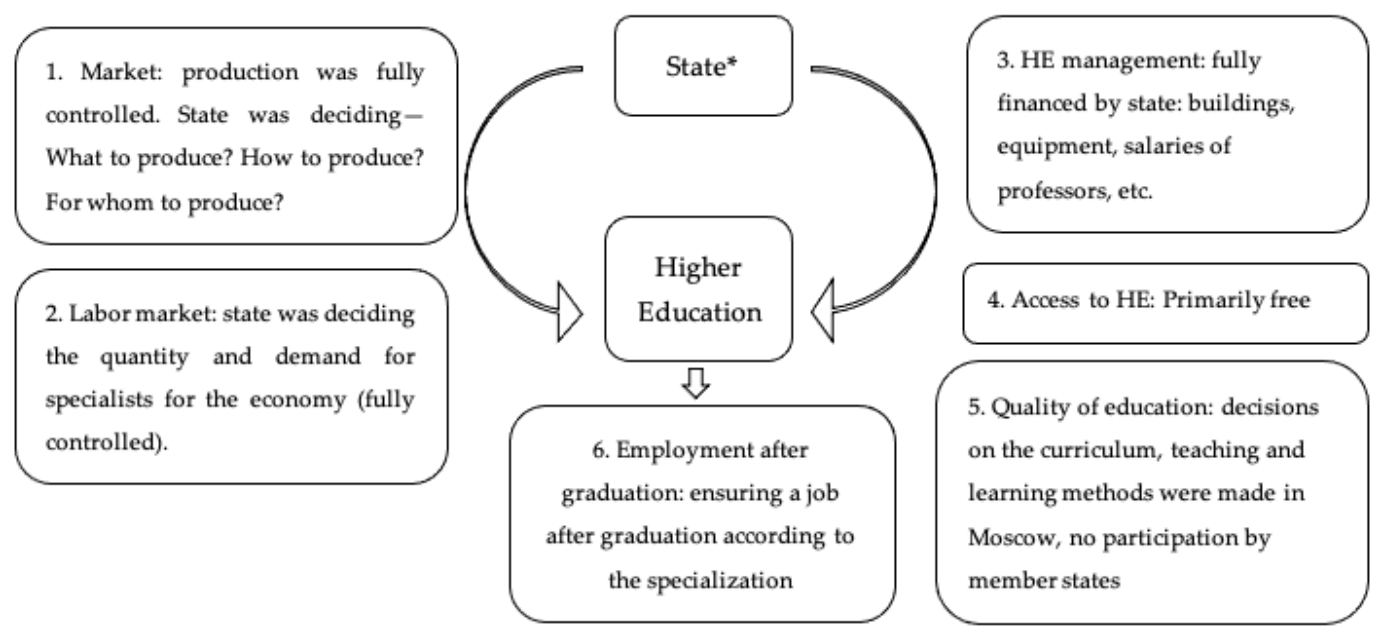

(a) Centralized system of higher education in the Soviet era (1922-1991). * Soviet Union, including all member states.

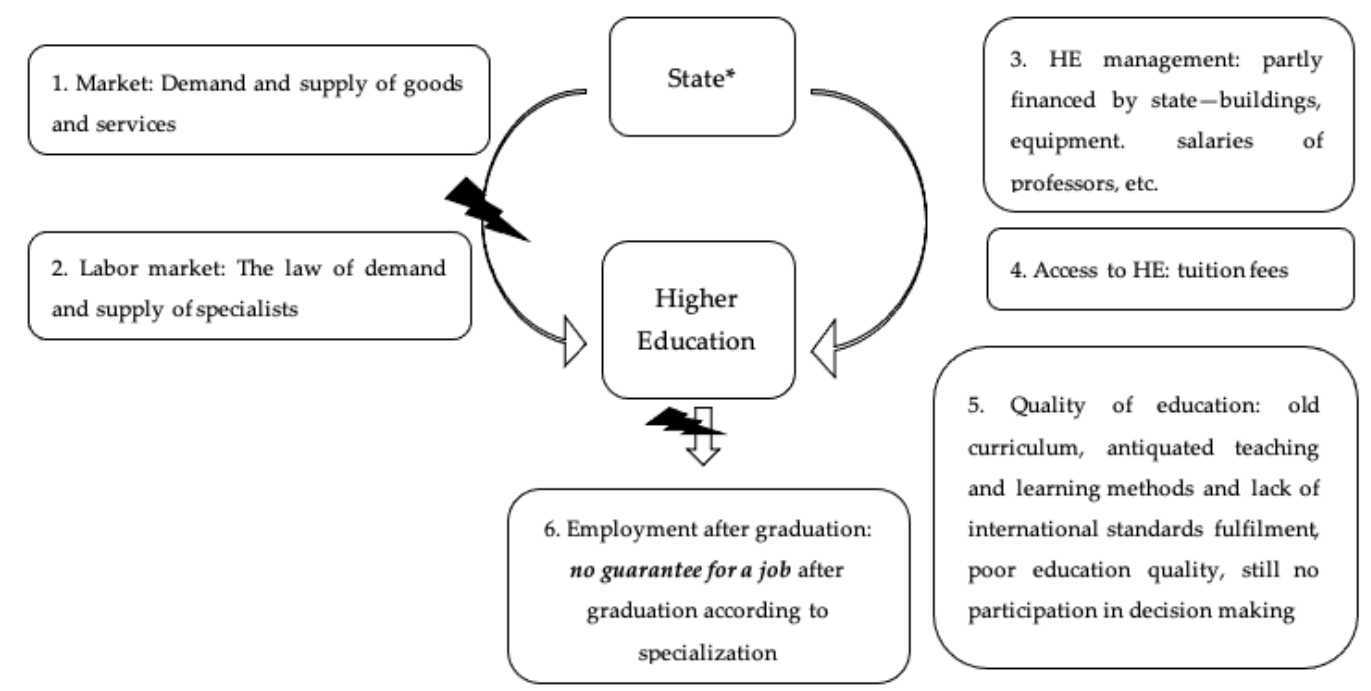

(b) The current higher education system in former Soviet Union member states (1991-2021). ${ }^{*}$ Already independent states, separately

Figure 5. Higher education systems in the Soviet era and after the collapse: drivers and barriers. Source: The figure was made by the authors by collecting and summarizing the information from the review process.

Armenia recently oriented its HEIs toward Western models, citing goals of increasing institutional ties with Western Europe and international organizations, and participation in the Bologna Process since 2005 [4]. Membership in the Bologna Process (with obligations to fulfill by 2010) provided a strong reform impetus [4]. Though scholars [37,38] note that Russian involvement in HE in the Southern Caucasus is largely limited to research projects or cultural exchange, there is little evidence on the modernization of HE to Western standards [4]. Yet, Armenia has strategically designed new HE systems (e.g., accreditation, quality assurance, university management structures) to endorse political control over HEIs.

The Armenian HE system is represented by the universities and other educational institutions by carrying out higher training programs, and is provided in a two-level system: bachelor's and master's programs at both state and private education institutions. This is congruent with most post-Soviet countries. Within Armenian higher educational institutions, 7000 members are teaching staff, of whom less than 2000 are working in the 
field. Student enrollment in 2019 was 9512 students in bachelor's programs and 5732 in master's programs, and the total number of students was 69,622 in bachelor's programs and 10,855 in master's programs.

Finally, Armenia's geographic location has generated serious challenges for security and economic development, and is strongly influenced by political factors with regard to its neighbors. Having no diplomatic relations with two neighbors, [39] Turkey and Azerbaijan, the country highly depends on Georgia and Iran for their land connection to the North and South. Naturally, these relations highly impact HE institutions' ability to contribute to regional and national sustainability due to the education sector's ties to policy, and to open exchange and knowledge production.

\subsection{Challenges of Higher Education in Armenia}

As illustrated above with the two most recent educational systems in Armenia, there are many challenges in HE today. The challenges identified in the literature in Armenian HE have been organized by clustering them into larger categories (Table 3).

Table 3. Clusters of the challenges of HE in post-Soviet countries (example of Armenia).

\begin{tabular}{|c|c|c|c|}
\hline Personnel & Curricula & Institutional & Quality Education \\
\hline $\begin{array}{l}\text {-Teacher } \\
\text { shortage }[33,40,41] \\
\text {-The feminization of } \\
\text { teaching profession [33] } \\
\text {-An over-aged teaching } \\
\text { force [39] }\end{array}$ & $\begin{array}{l}\text {-Planned and politically tied } \\
\text { curricula [14] } \\
\text {-Poor connection to } \\
\text { "real-world" problems [3,14] } \\
\text {-Modernization problems (not } \\
\text { available for international } \\
\text { exchange) }[14,16,42]\end{array}$ & $\begin{array}{l}\text {-Challenging starting point for } \\
\text { HE modernization }[4,14,16] \\
\text {-Low salaries [40] } \\
\text {-Low mobility [4] } \\
\text {-Corruption [4] } \\
\text {-Not well-researched [14] } \\
\text {-Decrease of enrollment in teacher } \\
\text { education programs [41] } \\
\text {-Low transition rate from teacher } \\
\text { education graduation to } \\
\text { professional service [41] } \\
\text {-Separation of teaching and } \\
\text { research [40] } \\
\text {-High concentration of HEIs in the } \\
\text { capital city [40] } \\
\text {-Lack of international standards } \\
\text { fulfilment }[4,41,43] \\
\text {-Hierarchical structures [44] }\end{array}$ & $\begin{array}{l}\text {-Incompatible or poor } \\
\text { teaching quality }[4,44] \\
\text {-Lack of infrastructure and } \\
\text { technology [45] } \\
\text {-Lack of library resources and } \\
\text { research laboratories [42] } \\
\text {-Obligatory preparatory } \\
\text { lessons for admission } \\
\text { examinations }[22,46]\end{array}$ \\
\hline
\end{tabular}

Source: The table was made by the authors by collecting and summarizing the information from the review process.

Although we have tried to generalize the challenges and pathways of all post-Soviet countries' HE, we realized that-as different countries chose different directions and paths of development-the characteristics and peculiarities of such a transformation process are unique to each country. Table 3 summarizes the discussed challenges that educational reform in post-Soviet countries continues to face from the very beginning of the transformation process. However, a lack of managerial skills creates difficulties at any stage of reform, and in fact hinders the process of decentralization [35].

\subsection{The Need for Transformation}

In education, the curriculum represents a selection of knowledge, skills, and values that shapes teaching methods, learning outcomes, and assessment ways [47]. The borders and types of involvement with curriculum development will understandably vary from one curriculum to another [24]. Traditional curriculum development is usually led by university experts, following a hierarchical, or lecture-based course system [48]. This may result in respective programs or courses that are old-fashioned, with teaching methods not necessarily contributing to the development of students' analytical, critical, and innovative thinking capacities [39]. The document analysis of the two Armenian universities' open- 
access documents on curriculum designing also confirmed this assessment. Following the participatory paradigm, adapted to today's needs and demands of the labor market, for scientific skills and thematic foci and of society, expertise comes from the wider stakeholder community, such as subject experts, students, private companies, etc. [49]. These stakeholders are experts in their own spheres, and by taking co-ownership of the educational process, they are able to make significant contributions toward creating more relevant and more effective learning [7]. A perception often held by teachers is that the curriculum is designed "elsewhere", and their job is a "correct application" of a curriculum that is "handed down to them from the top" [24]. Scholars [24,40] on the other hand recommend that teachers should be part of the "game", as teachers are the most important resource in education programs [6,50]. Below, we discuss the importance of other stakeholder's involvement in the process as well.

Sustainability within HE has been discussed from different perspectives-sustainability at the university level, HE curriculum on sustainability, and competencies in education for sustainable development [51-53].

HE focused on sustainability has introduced the need for a change in curricula for many degree programs [52]. Achieving sustainable HE also requires changes in other areas such as teaching and learning methods. Such modern methods often include transdisciplinary, holistic, and system thinking [5]. Stakeholder participation is also highly recommended for an improved curricula [7] that reaches students, future employers, community members, staff, and professors, building upon and drawing connections between the stakeholders. Although time-consuming, this has been noted to create dynamic and successful curricula relevant for many if not all stakeholders [48]. One purpose of stakeholder participation in education and curriculum development is to share the power of decision-making between both the teachers and the students, among other relevant stakeholders [54]. In a traditional (centralized) education curriculum, decisions are made by the teaching institution and by the teacher classroom procedures. Through student participation in education and curriculum development, as in other forms of development, the aim is to involve participants in decision-making as much as possible-from project and course work to curriculum and program development [21]. This is manifested in many different ways, but often includes elements, such as what, when, where, how and in what order to learn [55]. Important factors for supporting student stakeholder participation are as follows [56]:

- Motivation of students, as they feel responsible for their own learning programs;

- Teaching material is more relevant, as it reflects the learning needs of the students;

- The learning process is more permanent, as the students are more likely to independently continue learning the subjects in which they are interested, even if the courses are over.

This process is often called "negotiating the curriculum" with the students. PCD goes further than this, however. It tries to identify (beyond the teachers and the students) other parties that may be interested in or affected by the learning program, as well as integrating them at many if not all stages of development. Usually, these people are called "stakeholders" [57-59]. PCD seeks to ensure the participation of the wider group in devising the curriculum [60].

The substance and the boundaries of teacher involvement is often stimulated by conceptualization. This phenomenon has already been largely introduced in the literature [61-64]. Carl (2005) stated that in the earlier stages of curriculum design, teachers experience a strong wish to be a part of it. Two main tendencies are described in the literature in regard to teacher participation [24]:

- Teachers are hardly identified as the "recipients" of the curriculum, which is not developed by them. They limit their function as teachers only to the correct application of the curriculum. This is the nature of the "top-down" approach, which is pernicious to "the process of taking ownership of the curriculum"; 
- Teachers become partners in the process of curriculum transformation. Therefore, they should be given the chance to give input during the initial curriculum design process.

The existing educational system in any given institution determines the triumphs of these two interpretations: the nature and degree of participation [24].

Teacher involvement is important, not only for institutional reforms, but also for nourishing the personal and professional growth of teachers themselves [19]. Carl (2005) mentioned that meaningful strategies must be established to address the issues of teacher participation and their professional growth effectively [24]. Other scholars went on to say that curriculum development rests on teachers' personal development and professionalism [65]. Additionally, teachers' participation in curriculum development from early stages is largely directed by officials_administrators who do not have experience in teaching [65]. Those involved in the beginning of change more willingly accept new ideas than those who aren't involved. Even in the developed countries with well-educated and trained teachers, curriculum innovations were unlikely to be accepted unless teachers were involved in the process from the beginning [65].

What may be necessary to take into consideration is that teachers and students have divergent views of curriculum designing. So, what might be students' contribution to the curriculum design that teachers are not able to provide [66]? Trowler, P. and Trowler, V. (2010) noted that although much has been written about teacher-designed curricula, there is still need for more studies of student engagement in the curriculum-development process [67]. Though the extent of student involvement may be restricted by criteria such as group size; perception of risk [68]; and staff experience, confidence, and openness [69], their voices should be highly considered during the curriculum-design process, as they have a central role as learners.

It is important to note that PCD does have its challenges. In comparison to more traditional approaches, PCD requires more time and other resources; it is not easy to keep stakeholders motivated during the whole process, and it is quite challenging to create an equal communication mechanism for various stakeholders because of different understandings, experiences, and educational backgrounds [49]. Additionally, educational developers must have proper skills in qualitative data collection in order to stage efficient PCD processes. The stakeholder management is needed to ensure recognition, analysis, and examination of individual and group characteristics [70]. Participants with different degrees of power and interests should be maintained accordingly, which can be timeconsuming [71]. Moreover, various participants may have competing priorities, preferences, and values, which can lead to high stakeholder turnover rates [48].

Based on the comprehensive investigation of curriculum-development practices in $\mathrm{Ar}$ menian HEIs, it can be argued that one of the crucial historical obstacles to the participatory, sustainable approach is "curricula dovetailing", which is a subversive practice of curriculum development. It occurs when the required competences, modules, or subjects are designed in a way that best fit the existing teaching staff and their preferences-regardless of whether those subjects and the corresponding learning outcomes are necessary for the future specialists or required by the labor market at all—instead of being shaped through the intended learning outcomes and in case of PCD stakeholder needs and participation. In other words, subjects are simplistically adjusted to the existing academic staff's circumstances instead of recruiting suitable professors or offering additional training that could provide the implementation of the learning outcomes at an appropriate level. Thus, curricula dovetailing is a process of inverted curriculum design.

The existence of uncertainties in state regulations is another problem for effective and participatory curriculum development in post-Soviet HEIs. For instance, there are various contradictions in Armenian university rules and regulations that do not allow universities to develop sustainable processes of curriculum design. In fact, the state standards for specializations and qualifications, envisaged by the law on HE, currently are not functioning anymore. The reason is that the government adopted a new piece of legislation on the list of specializations and qualifications in 2015; however, until now it has 
not developed new standards in correspondence with the new list. Thus, the old standards are legally outdated and void, because they refer to an obsolete list of specializations and qualifications. Moreover, the ministry of education has drafted a new law applying to $\mathrm{HE}$, in which there is a paradigm shift from traditional "state standards" to a "sectoral qualifications framework". However, because the law has not been adopted yet, those who are responsible for the development of standards or qualifications framework are in fact technically "paralyzed" by the legal ambiguity. Hence, Armenian universities currently develop their curricula essentially based on nothing-there are neither standards nor qualification frameworks.

The existing problems are exacerbated when it comes to the master's level. The shift from the traditional one-tier system (diploma specialist) to the separation of bachelor's and master's degrees has mostly taken a formal character. The practice of curriculum design at a master's level shows that it has effectively grown into a regurgitation of the bachelor's programs with slightly modified subject titles, but mostly with the same academic staff and the content. This reality is also reflected in the significant and persistent reduction in the enrollment rate of master's programs in the recent years. There is no clear comprehension of the distinction between the two levels. Universities, students, the labor market, etc., have yet to develop their actual practices for emphasizing the significance and the role of a master's degree. They instead perceive it as two additional years of the same higher education. The main reason is the absence of clear strategy and policies when the system was changed. The only reference point for the Armenian academic community was the government act on the national qualifications' framework (https: / / www.arlis.am/DocumentView.aspx?docid=66856; accessed on 13 May 2021), which contains merely several sentences to describe the master's level with rather generic and ambiguous formulations.

\section{Discussion and Conclusions}

This article situated Armenia-a small state with strong external dependency-as a country with serious political and geographical challenges for national policy, security, and sustainable development, whose effects trickle down to the current HE system. The results of this study show that after the fall of communism, educational systems in all former Soviet member countries are still going through a transformational process, and for Armenia in particular, political control and interest over the universities still exists, which hinders reform. Some special programs have shown success with modernization, but the majority is still bogged down by the antiquated and oppressive Soviet-style system.

PCD and modernized education systems do not focus only on job markets, but also other functions of universities: as agents of change, bringing about sustainability, critically challenging existing systems, knowledge and technology development/production, etc. The latest findings illustrate that no formal barriers exist for the universities to expand their roles [72].

The positive consequences of PCD outlined above could push Armenian universities toward supporting ecological, economic, and social sustainability. However, the challenges without specific governmental help and HEI staff understanding prolongs such transformations.

Rather than promoting universities as agents of change towards sustainable and regional development, "dovetailing" has been found as the solution to needed curriculum change, a particular underlying problem for Armenian HEIs. State universities have therefore created a destructive "informal" and implicit mission of serving as institutions of social protection for those staff members who had been working there for decades and have become in fact inviolable. A vast amount of the professors had once been called to join the department through nepotism, patronage, bribery, or other types of corruption. As this generally occurred many years ago, their presence is now indisputable-regardless of their professional qualities. 
Provided the above-described reality, the potential reforms in HEIs for embedding more efficient curricula-design practices usually encounter strong resistance from different groups of interests, who are concerned with the risk of losing their positions if the programs of studies are developed in accordance with the real requirements of the labor market and other stakeholder groups. Meanwhile, because the number of entrenched professors is still large, state authorities are also reluctant to encourage such pivotal changes by the state universities, as they might lead to discontent among the low-skilled professors and possible tensions that are rather undesirable for them. Thus, even if the comprehension of the necessity of curricula development reforms in Armenia is not a significant problem, the steps to implementation are difficult, resulting in actual processes that are either absent or terminated by conservative authorities.

This literature review described the nature of HE in post-Soviet countries being more top-down, and stated that integration of students and a wide range of stakeholders into the curricula development can shift the system to a more bottom-up model. Such integrative approaches secure the integration of a broader view and expertise on what might be relevant contents for teaching and learning. As quality of HE directly influences the social and economic development of a country [16], the curriculum is the instrument in which the overall teaching and learning program is described, and in which the general content of a teaching program is defined. Through continuous reform in the curricula-designing process, the modernization of higher education is essential [40]. The modernization of HE should target curricula reforms in a way to provide not only knowledge, but also empower students with practical skills [41].

Discussing the two different models of HE together with their advantages and disadvantages was not the main focus of this article, but rather the underlining of the instabilities and challenges the current higher educational system is facing, and how participation can contribute to overcoming them. Yet, these differing models illustrated the need for further development.

Here, we highlighted the current scientific discourse on the higher education systems in post-Soviet countries, focusing on the shift to sustainable higher education and using Armenia as an example, as it is one of the 15 states that currently is trying to overcome the transition-period challenges of the HE. Moreover, transition is an ill-defined, uncertain process aimed to create democratic societies during the shift from a centralized to a market economy system [73]. Our article provided insight on how far the transformation of teaching and learning in higher education took place in post-Soviet countries. With this, we provided a summary of the status quo of HE-still having a top-down approach, not meeting the demand of "real-world" problems, and having a weak connection with the labor market. Finally, we underline the needs for further curriculum development (bottomup approach, more active learning, new teaching methods, etc.), that are inexplicably linked to sustainable higher education. After the Armenian Velvet revolution in 2018, efforts have been made at the university level to bring about reforms in higher education. Up until now, the desired objectives of education have not yet been achieved.

A change should be thoroughly planned through high investigation of the curriculum users, the stakeholders of the value chain. Educators should be trained in order to become reflective practitioners [65]. However, looking at current educational policies, it becomes obvious that curriculum developers failed to translate this objective into curriculum design [65]. As a result, a majority of the goals remain unfulfilled. Teachers should also be motivated in a way to enrich and update their curricula according to classroom requirements [16]. This will create a climate of professionalism among the educators who are the real decision-makers for the curriculum implementation in their classrooms. [65]. In shaping a framework for curricula development based on a bottom-up and participatory approach, the foundation for a transition to sustainable higher education may be created. With stakeholder integration, specific sustainable characteristics and actions can be identified and integrated in fields of curricula, as well as impacts on real-world problems. Universities have the possibility and capacity to act as agents of change and 
improve regional and sustainable development, as they advance and translate science and its relevancy through students and outside stakeholders. This literature review illustrated that participation in curriculum development has the potential to contribute to a sustainable HE, particularly in Armenia and other post-Soviet countries struggling with similar HE challenges.

Author Contributions: Conceptualization, H.H. and M.K.; methodology, H.H.; software, H.H.; validation, H.H., M.K., B.F., and R.H.; formal analysis, H.H.; investigation, H.H.; resources, H.H., M.K., and R.H.; data curation, H.H.; writing-original draft preparation, H.H.; writing-review and editing, H.H., M.K., B.F., and R.H.; visualization, H.H.; supervision, M.K. and B.F.; project administration, M.K.; funding acquisition, H.H., M.K., and B.F. All authors have read and agreed to the published version of the manuscript.

Funding: The Ph.D. studies of Hasmik Hovakimyan (corresponding author) have been financed by the Austrian Partnership Programme in Higher Education and Research for Development-APPEAR, a programme of the Austrian Development Cooperation (ADC) and implemented by the Austrian Agency for International Cooperation in Education and Research (OeAD). The grant specification number is OEZA Project number: 0894-00/2014.

Institutional Review Board Statement: Not applicable.

Informed Consent Statement: Not applicable.

Data Availability Statement: Not applicable.

Acknowledgments: The publication of this article in an Open Access journal was supported by Open Access (OA) Publishing Fund of the University of Natural Resources and Life Sciences, Vienna.

Conflicts of Interest: The authors declare no conflict of interest. The funders in no way influenced the process or the results of this study.

\section{References}

1. Strayer, R. Why Did the Soviet Union Collapse?: Understanding Historical Change; ME Sharpe: New York, NY, USA, 1998.

2. Platz, S. The Shape of National Time: Daily Life, History and Identity during Armenia's Transition to Independence 1991-1994. In Altering States: Ethnographies of Transition in Eastern Europe and the Former Soviet Union; The University of Michigan Press: Ann Arbor, MI, USA, 2000; pp. 114-138.

3. Smolentseva, A. Access to higher education in the post-Soviet States: Between Soviet legacy and global challenges. In Paper Commissioned and Presented at Salzburg Global Seminar, Session; Salzburg Global Seminars: Salzburg, Austria, 2012.

4. Dobbins, M.; Khachatryan, S. Europeanization in the "Wild East"? Analyzing higher education governance reform in Georgia and Armenia. High. Educ. 2015, 69, 189-207. [CrossRef]

5. Sterling, S. Higher education, sustainability, and the role of systemic learning. In Higher Education and the Challenge of Sustainability; Springer: Dordrecht, The Netherlands; Kluwer Academic Publishers: New York, NY, USA, 2004; pp. 49-70.

6. Beynaghi, A.; Trencher, G.; Moztarzadeh, F.; Mozafari, M.; Maknoon, R.; Leal Filho, W. Future sustainability scenarios for universities: Moving beyond the United Nations Decade of Education for Sustainable Development. J. Clean. Prod. 2016, 112, 3464-3478. [CrossRef]

7. Taylor, P. How Can Participatory Processes of Curriculum Development Impact on the Quality of Teaching and Learning in Developing Countries; Paper commissioned for the Education for All Global Monitoring Report; United Nations Educational Scientific and Cultural Organization: Paris, France, 2005.

8. Sedlacek, S. The role of universities in fostering sustainable development at the regional level. J. Clean. Prod. 2013, 48, 74-84. [CrossRef]

9. Berchin, I.I.; Sima, M.; de Lima, M.A.; Biesel, S.; dos Santos, L.P.; Ferreira, R.V.; Ceci, F. The importance of international conferences on sustainable development as higher education institutions' strategies to promote sustainability: A case study in Brazil. J. Clean. Prod. 2018, 171, 756-772. [CrossRef]

10. Rogers, P.P.; Jalal, K.F.; Boyd, J.A. An Introduction to Sustainable Development; Earthscan: London, UK, 2012.

11. Barbier, E.B. The concept of sustainable economic development. Environ. Conserv. 1987, 14, 101-110. [CrossRef]

12. Mason, M. Making educational development and change sustainable: Insights from complexity theory. Int. J. Educ. Dev. 2009, 29, 117-124. [CrossRef]

13. Gibbs, J. Gorbachev's Glasnost: The Soviet Media in the First Phase of Perestroika; Texas A\&M University Press: College Station, TX, USA, 1999. 
14. Smolentseva, A.; Huisman, J.; Froumin, I. (Eds.) Transformation of Higher Education Institutional Landscape in Post-Soviet Countries: From Soviet Model to Where? In 25 Years of Transformations of Higher Education Systems in Post-Soviet Countries: Reform and Continuity; Springer International Publishing: Cham, Switzerland, 2018; pp. 1-43.

15. Kerr, S.T. Research news and Comment: Will Glasnost Lead to Perestroika? Directions of Educational Reform in the USSR. Educ. Res. 1990, 19, 26-31. [CrossRef]

16. Shahverdyan, A. The Mismatch of Higher education (supply) and the labor market (demand). Kantegh A Collect. Sci. Artic. 2009, 3, 249-254. (In Armenian)

17. Disterheft, A.; da Silva Caeiro, S.S.F.; Ramos, M.R.; de Miranda Azeiteiro, U.M. Environmental Management Systems (EMS) implementation processes and practices in European higher education institutions-Top-down versus participatory approaches. $J$. Clean. Prod. 2012, 31, 80-90. [CrossRef]

18. Blonder, R.; Kipnis, M.; Mamlok-Naaman, R.; Hofstein, A. Increasing Science Teachers' Ownership through the Adaptation of the PARSEL Modules: A “Bottom-up” Approach. Sci. Educ. Int. 2008, 19, 285-301.

19. Leisyte, L.; Westerheijden, D.F. Stakeholders and Quality Assurance in Higher education. In Drivers and Barriers to Achieving Quality in Higher Education; Brill Sense: Leiden, The Netherlands, 2014; pp. 83-97.

20. Matkovic, P.; Tumbas, P.; Sakal, M. University Stakeholders in the Analysis Phase of Curriculum Development Process Model. In Proceedings of the 7th International Conference of Education, Research and Innovation (ICERI), Seville, Spain, 17-19 November 2014.

21. Koehn, P.H.; Rosenau, J.N. Transnational Competence: Empowering Curriculums for Horizon-Rising Challenges; Routledge: New York, NY, USA, 2015.

22. Kazdanyan, S. Active Learning as a Way to Increase Students' Motivation. In Conference Proceedings; Armenia-Russian University: Moscow, Russia, 2015. (In Russian)

23. OECD. Higher Education Management and Policy. In Journal of the Program on Institutional Management in Higher Education; OECD Publication Service: Paris, France, 2004.

24. Carl, A. The "voice of the teacher" in curriculum development: A voice crying in the wildernes. S. Afr. J. Educ. 2005, 25, 223-228.

25. Kitchenham, B.; Charters, S. Guidelines for Performing Systematic Literature Reviews in Software Engineering; Version 2.3, EBSE 2007-001, Keele University and Durham Univeristy Joint Report; Keele University: Keele, UK; Durham Univeristy: Durham, UK, 2007; pp. 1-57.

26. Moher, D.; Liberati, A.; Tetzlaff, J.; Altman, D.G. Preferred reporting items for systematic reviews and meta-analyses: The PRISMA statement. PLoS Med. 2009, 6, e1000097. [CrossRef]

27. Stuckey, H.L. The second step in data analysis: Coding qualitative research data. J. Soc. Health Diabetes 2015, 3, 8. [CrossRef]

28. Rivas, C. Coding and analysing qualitative data. Res. Soc. Cult. 2012, 3, 367-392.

29. Cooper, H. Research Synthesis and Meta-Analysis: A Step-by-Step Approach, 5th ed.; Sage Publications: Thousand Oaks, CA, USA, 2015; Volume 2.

30. Thomas, D.R. A general inductive approach for analyzing qualitative evaluation data. Am. J. Eval. 2006, 27, 237-246. [CrossRef]

31. Prokofiev, M.; Chilikin, M.; Tulpanov, S. Higher Education in the USSR. Vol. Educational Studies and Documents, N39. 1961, Paris: UNESCO. 59. Available online: https:/ / files.eric.ed.gov/fulltext/ED544054.pdf (accessed on 5 May 2021).

32. Ghukasyan, A.; Asatryan, L.; Karapetyan, A. "Management of Pedagogical University and Development Trends" Scientific-Methodical Manual; Mankavarzh: Yerevan, Armenia, 2005. (In Armenian)

33. Silova, I. The crisis of the post-Soviet teaching profession in the Caucasus and Central Asia. Res. Comp. Int. Educ. 2009, 4, 366-383. [CrossRef]

34. Kozma, T.; Polonyi, T. Understanding education in Europe-East: Frames of interpretation and comparison. Int. J. Educ. Dev. 2004, 24, 467-477. [CrossRef]

35. Zelvys, R. Development of education policy in Lithuania during the years of transformations. Int. J. Educ. Dev. 2004, 24, 559-571. [CrossRef]

36. Höltge, K. Governance in Transition. In What Makes Georgia's Higher Education System So Corrupt? Kassel University Press GmbH: Kassel, Germany, 2009.

37. Nixey, J. The Long Goodbye: Waning Russian Influence in the South Caucasus and Central Asia; Chatham House: London, UK, 2012.

38. Kivirähk, J. The «Humanitarian Dimension» of Russian Foreign policy Toward Georgia, Moldova, Ukraine, and the Baltic States; Centre for East European Policy Studies: Riga, Latvia, 2009.

39. Navoyan, A. Tertiary education in Armenia: Between Soviet heritage, transition, and the Bologna Process. In Tertiary Education in Small States: Planning in the Context of Globalization; International Institute for Educational Planning: Paris, France, 2011; pp. 193-211.

40. Kazdanyan, S. To the Question about Pedagogical Activities at the Higher Educational Institutions. In Conference Proceedings; Armenia-Russian University: Yerevan, Armenia, 2015. (In Russian)

41. Khachatryan, N. Social Orientation Issues of Professional Education. Kantegh A Collect. Sci. Artic. 2017, 2, 154-167. (In Armenian)

42. Sekhposyan, A. Problems of Modernization of the Higher Education System in the Republic of Armenia. Master's Thesis, Defenced at the Public Administration Academy of the Republic of Armenia, Yerevan, Armenia, 2018. (In Armenian).

43. Petrosyan, H. Issues of Educational Program Accreditation. Lrab. Soc. Sci. 2007, 1, 112-125. (In Armenian) 
44. Karakhanyan, S.Y. Reforming Higher Education in a Post-Soviet Context: The Case of Armenia. Ph.D. Dissertation, Radbound University, Nijmegen, The Netherlands, 2011. [Sl: Sn].

45. Simonyan, T. The History of Armenian Pedagogy, from Ancient Times to the Present Days; Van Saryan: Yerevan, Armenia, 2012. (In Armenian)

46. Militonyan, L. The Main Approaches to a Professional Modular Educational Program Design; Bryusov State University: Yerevan, Armenia, 2016. (In Armenian)

47. Stabback, P. What Makes a Quality Curriculum? In-Progress Reflection No. 2 on "Current and Critical Issues in Curriculum and Learning"; UNESCO International Bureau of Education: Geneva, Switzerland, 2016.

48. Alexander, I.K.; Hjorts $\varnothing$, C.N. Sources of complexity in participatory curriculum development: An activity system and stakeholder analysis approach to the analyses of tensions and contradictions. High. Educ. 2019, 77, 301-322. [CrossRef]

49. Taylor, P. Improving forestry education through participatory curriculum development: A case study from Vietnam. J. Agric. Educ. Ext. 2000, 7, 93-104. [CrossRef]

50. Shaeffer, S. Participatory approaches to teacher training. In Teachers in Developing Countries: Improving Effectiveness and Managing Costs; International Institute for Educational Planning: Paris, France, 1993; pp. 187-200.

51. Cebrián, G.; Junyent, M.; Mulà, I. Competencies in Education for Sustainable Development: Emerging Teaching and Research Developments. Sustainability 2020, 12, 597. [CrossRef]

52. Ruesch Schweizer, C.; Di Giulio, A.; Burkhardt-Holm, P. Scientific Support for Redesigning a Higher-Education Curriculum on Sustainability. Sustainability 2019, 11, 6035. [CrossRef]

53. Solís-Espallargas, C.; Ruiz-Morales, J.; Limon-Dominguez, D.; Valderrama-Hernandez, R. Sustainability in the University: A Study of Its Presence in Curricula, Teachers and Students of Education. Sustainability 2019, 11, 6620. [CrossRef]

54. Stefanou, C.R.; Perencevich, K.C.; DiCintio, M.; Turner, J.C. Supporting autonomy in the classroom: Ways teachers encourage student decision making and ownership. Educ. Psychol. 2004, 39, 97-110. [CrossRef]

55. Chapleo, C.; Simms, C. Stakeholder analysis in higher education: A case study of the University of Portsmouth. Perspectives 2010, 14, 12-20. [CrossRef]

56. OECD. Student assessment: Putting the learner at the centre. In Synergies for Better Learning: An International Perspective on Evaluation and Assessment; OECD Publishing: Paris, France, 2013. [CrossRef]

57. Maina, B.M. Influence of Stakeholders' Participation on the Success of the Economic Stimulus Programme: A Case of Education Projects in Nakuru County, Kenya. Master's Thesis, University of Nairobi, Nairobi, Kenya, 2013.

58. Tran, L.H.N. Game of blames: Higher education stakeholders' perceptions of causes of Vietnamese graduates' skills gap. Int. J. Educ. Dev. 2018, 62, 302-312. [CrossRef]

59. Small, L.; Shacklock, K.; Marchant, T. Employability: A contemporary review for higher education stakeholders. J. Vocat. Educ. Train. 2018, 70, 148-166. [CrossRef]

60. Percy, R. Participatory Curriculum Development in Agricultural Education: A Training Guide: Alan Rogers and Peter Taylor; Food and Agriculture Organisation (FAO): Rome, Italy, 1998; p. 154.

61. Connelly, F.M.; Clandinin, D.J. Teachers as Curriculum Planners. Narratives of Experience; ERIC: New York, NY, USA, 1988.

62. Imber, M.; Neidt, W.; Reyes, P. Teacher Participation in School Decision Making Teachers and Their Workplace: Commitment, Performance, and Productivity 1990 Newbury Park; Sage: London, UK, 1990; Volume 67, p. 85.

63. Fullan, M. The New Meaning of Educational Change; Routledge: London, UK; New York, NY, USA, 2001.

64. Carl, A. Teacher Empowerment through Curriculum Development: Theory into Practice; Juta and Company Ltd.: Cape Town, South Afrika, 2009.

65. Haider, G. Process of Curriculum Development in Pakistan. Int. J. New Trends Arts Sports Sci. Educ. 2016, 5, 15-20.

66. Brooman, S.; Darwent, S.; Pimor, A. The student voice in higher education curriculum design: Is there value in listening? Innov. Educ. Teach. Int. 2015, 52, 663-674. [CrossRef]

67. Trowler, P.; Trowler, V. Student Engagement Evidence Summary; The Higher Education Academy: Lancaster, UK, 2010.

68. Bovill, C. An investigation of co-created curricula within higher education in the UK, Ireland and the USA. Innov. Educ. Teach. Int. 2014, 51, 15-25. [CrossRef]

69. Bovill, C.; Cook-Sather, A.; Felten, P. Students as co-creators of teaching approaches, course design, and curricula: Implications for academic developers. Int. J. Acad. Dev. 2011, 16, 133-145. [CrossRef]

70. Wagner Mainardes, E.; Alves, H.; Raposo, M. A model for stakeholder classification and stakeholder relationships. Manag. Decis. 2012, 50, 1861-1879. [CrossRef]

71. Eden, C. Managerial and Organizational Cognition: Theory, Methods and Research; Sage: London, UK; Thousand Oaks, CA, USA; New Dehli, India, 1998.

72. Keryan, T.; Muhar, A.; Mitrofanenko, T.; Khoetsyan, A.; Radinger-Peer, V. Towards Implementing Transdisciplinarity in PostSoviet Academic Systems: An Investigation of the Societal Role of Universities in Armenia. Sustainability 2020, $12,8721$. [CrossRef]

73. Šlaus, I.; Šlaus-Kokotović, A.; Morović, J. Education in countries in transition facing globalization-A case study Croatia. Int. J. Educ. Dev. 2004, 24, 479-494. [CrossRef] 